\title{
Respons Pertumbuhan Vegetatif Binahong (Anredera cordifolia (Ten.) Steenis) Terhadap Aplikasi Pupuk Organik Cair
}

Response of vegetative growth of binahong on application of liquid organic fertilizer

\section{Jamson Hasintongan Tampubolon, Yaya Hasanah*, dan Jonis Ginting}

Program Studi Agroteknologi, Fakultas Pertanian, USU Medan, 20155

*Corresponding author : yaya@usu.ac.id

\begin{abstract}
This research has been conducted to obtain the response of vegetative growth of anredera to the application of liquid organic fertilizer. This research has been conducted at experimental Field of Faculty of Agriculture, University of Sumatera Utara, Medan, January - April 2017. The research method used non factorial randomized block design with 6 treatment levels: 0; 2,5; 5,0; 7,5; 10,0 and 12,5 ml/l. Parameters observed were plant length, number of leaves, fresh weight of canopy, fresh root weight, root dry weight. The results showed that the application of liquid organic fertilizer with a concentration of $12.5 \mathrm{ml} / \mathrm{l}$ significantly effected on the growth of plant length and number of leaves. Giving of liquid organic fertilizer with concentration 12, $50 \mathrm{ml} / \mathrm{l}, 2.50 \mathrm{ml} / \mathrm{l}, 5,00 \mathrm{ml} / \mathrm{l}, 7,50$ $\mathrm{ml} / \mathrm{l}$, and $10 \mathrm{ml} / \mathrm{l}$ show no real effect on the concentration on the fresh of plant crown weight. Provision of liquid organic fertilizer with a concentration of $7.50 \mathrm{ml} / \mathrm{l}$ significantly effected to increase the growth of fresh root weight and root dry weight of binahong plants.
\end{abstract}

Keywords : Anredera, concentrations of liquid organic fertilizer, vegetative growth

\begin{abstract}
ABSTRAK
Penelitian ini bertujuan untuk mengetahui respons pertumbuhan vegetatif binahong terhadap aplikasi pupuk organik cair. Penelitian ini dilaksanakan di Lahan Praktikum Fakultas Pertanian Universitas Sumatera Utara, Medan, pada bulan Januari 2017 hingga April 2017. Metode penelitian menggunakan Rancangan Acak Kelompok non faktorial dengan 6 taraf perlakuan, yaitu : 0; 2,5; 5,0; 7,5; 10,0 dan 12,5 ml/1. Parameter yang diamati adalah Panjang tanaman, jumlah daun, bobot segar tajuk, bobot kering tajuk, bobot segar akar, dan bobot kering akar. Hasil penelitian menunjukkan bahwa pemberian pupuk organik cair dengan konsentrasi $12,5 \mathrm{ml} / \mathrm{l}$ memberikan pengaruh nyata meningkatkan pertumbuhan panjang tanaman dan jumlah daun. Pemberian pupuk organik cair dengan konsentrasi $12,50 \mathrm{ml} / 1,2,50 \mathrm{ml} / 1,5,00 \mathrm{ml} / 1,7,50 \mathrm{ml} / 1$, dan $10 \mathrm{ml} / 1$ memberikan pengaruh tidak nyata terhadap konsentrasi pada bobot segar tajuk. Pemberian pupuk organik cair dengan konsentrasi 7,50 ml/1 memberikan pengaruh nyata meningkatkan pertumbuhan bobot segar akar dan bobot kering akar.
\end{abstract}

Kata kunci : binahong, konsentrasi pupuk organik cair, pertumbuhan vegetatif 


\section{PENDAHULUAN}

Perkembangan industri jamu, obat herbal, fitofarmaka dan kosmetika tradisional mendorong berkembangnya budidaya tanaman obat di Indonesia. Salah satu tanaman yang biasa dimanfaatkan untuk pengobatan herbal adalah binahong. Saat ini tanaman binahong masih dikembangkan secara perorangan dan belum diketahui teknik budidaya yang tepat (Tatik et al. 2014).

Binahong dengan nama ilmiah Anredera cordifolia (Ten) Steenis tergolong famili dari Basellaceae yang merupakan tanaman obat yang sudah tumbuh sejak lama. Di Indonesia binahong belum dikenal secara luas, namun di Vietnam tanaman ini sangat diperlukan bahkan di Taiwan sering dijadikan sebagai sayuran (Astuti, et al. 2011).

Perbanyakan tanaman binahong secara vegetatif umumnya dilakukan dengan menggunakan setek batang. Setek batang pada umumnya lebih mudah dan sangat menguntungkan karena batang mempunyai persediaan bahan makanan yang cukup, terdapat tunas-tunas, dan jaringan meristem yang membentuk akar (Mus, 2008).

Penambahan pupuk organik cair merupakan salah satu cara untuk meningkatkan pertumbuhan tanaman dan kandungan unsur hara dalam tanah. Pemberian pupuk organik mampu meningkatkan pertumbuhan dan hasil tanaman. Pemberian pupuk organik cair dapat meningkatkan pertumbuhan tanaman. (Atmojo, 2003).

Tujuan penelitian ini adalah untuk mengetahui respons pertumbuhan vegetatif binahong terhadap aplikasi pupuk organik cair.

\section{BAHAN DAN METODE}

Penelitian ini dilaksanakan di Lahan Percobaan Fakultas Pertanian USU Medan dengan ketinggian tempat \pm 25 mdpl. Dengan menggunakan Rancangan Acak Kelompok (RAK) Non Faktorial dengan 4 ulangan, konsentrasi pupuk organik cair (POC) yang hendak diaplikasikan pada 2, 3, 4, 5, dan 6 Minggu setelah tanam (MST), yaitu : $\mathrm{K}_{0}=$ Tanpa Perlakuan, $\mathrm{K}_{1}=2.5 \mathrm{ml} / \mathrm{l}, \mathrm{K}_{2}=5.0 \mathrm{ml} / \mathrm{l}$,
$\mathrm{K}_{3}=7.5 \mathrm{ml} / \mathrm{l}, \mathrm{K}_{4}=10 \mathrm{ml} / \mathrm{l}, \mathrm{K}_{5}=12.5 \mathrm{ml} / \mathrm{l}$. Bahan yang digunakan dalam penelitian antara lainbahan tanam umbi ketiak daun dari binahong, pupuk organik cair, top soil, air, polibeg, bambu, plastik, paku, kawat dan label.

Alat yang digunakan dalam penelitian antara lain timbangan analitik, ayakan, cangkul, mistar, meteran, tali plastik, gembor, gelas ukur, pipet tetes, corong, parang, gergaji, martil, dan alat-alat tulis.

Pelaksanaan penelitian meliputi Persiapan media tanam dilakukan dengan mengayak media tanam top soil dengan ayakan yang berfungsi untuk menggemburkan struktur media tanah. Bagian organ tanaman yang digunakan untuk penelitian ini adalah umbi ketiak daun.

Penanaman dilakukan dengan cara menanam bahan tanam ke dalam media tanam yang ditugal dengan kedalaman $2 \mathrm{~cm}$ kemudian dan dipadatkan secara merata. Penyiraman dilakukan setiap 2 kali sehari tergantung pada kondisi cuaca. Pengajiran dilakukan pada saat tanaman berumur 5 MST.

Penyiangan dilakukan untuk membersihkan gulma yang ada dalam polibeg dan juga gulma yang ada pada areal lahan penelitian. Pupuk organik cair yang memiliki kandungan Moisture 96,64\%, N (0.20\%), $\mathrm{P}_{2} \mathrm{O}_{5}$ $(0,03 \%), \mathrm{K}_{2} \mathrm{O}(0,15 \%)$, C-organik $(1,66 \%)$, dan $\mathrm{pH}(3,34 \%)$. Data pengamatan dianalisis dengan sidik ragam rancangan acak kelompok (RAK) non faktorial. Jika efek perlakuan berbeda nyata dilanjutkan dengan uji beda nyata jujur (BNJ) pada taraf $\alpha=5 \%$.

\section{HASIL DAN PEMBAHASAN}

\section{Panjang Tanaman}

Tabel 1 menunjukkan bahwa pada umur 5-8 MST panjang tanaman binahong tertinggi diperoleh pada perlakuan konsentrasi pupuk organik cair 12,50 $\mathrm{ml} / \mathrm{l}\left(\mathrm{K}_{5}\right)$ yang berbeda tidak nyata dengan $\mathrm{K}_{1}, \mathrm{~K}_{2}, \mathrm{~K}_{3}$ dan $\mathrm{K}_{4}$, namun berbeda nyata dengan $\mathrm{K}_{0}$. 
Tabel 1. Panjang tanaman binahong umur 5-8 MST pada perlakuan konsentrasi pupuk organik cair

\begin{tabular}{clc}
\hline $\begin{array}{c}\text { Pengamatan } \\
(\text { MST) }\end{array}$ & \multicolumn{1}{c}{$\begin{array}{c}\text { Konsentrasi } \\
\text { Pupuk Organik Cair (ml/l) }\end{array}$} & $\begin{array}{c}\text { Rataan } \\
(\mathrm{cm})\end{array}$ \\
\hline 5 & $\mathrm{~K}_{0}$ (Tanpa Perlakuan) & $26,94 \mathrm{~b}$ \\
& $\mathrm{~K}_{1}(2,5)$ & $83,54 \mathrm{ab}$ \\
& $\mathrm{K}_{2}(5,0)$ & $105,54 \mathrm{ab}$ \\
& $\mathrm{K}_{3}(7,5)$ & $126,63 \mathrm{a}$ \\
& $\mathrm{K}_{4}(10,0)$ & $140,15 \mathrm{a}$ \\
& $\mathrm{K}_{5}(12,5)$ & $156,15 \mathrm{a}$ \\
\hline 6 & $\mathrm{~K}_{0}($ Tanpa Perlakuan) & $34,46 \mathrm{~b}$ \\
& $\mathrm{~K}_{1}(2,5)$ & $99,56 \mathrm{ab}$ \\
& $\mathrm{K}_{2}(5,0)$ & $122,50 \mathrm{ab}$ \\
& $\mathrm{K}_{3}(7,5)$ & $149,24 \mathrm{a}$ \\
& $\mathrm{K}_{4}(10,0)$ & $156,33 \mathrm{a}$ \\
& $\mathrm{K}_{5}(12,5)$ & $177,16 \mathrm{a}$ \\
\hline 7 & $\mathrm{~K}_{0}($ Tanpa Perlakuan $)$ & $45,19 \mathrm{~b}$ \\
& $\mathrm{~K}_{1}(2,5)$ & $112,53 \mathrm{ab}$ \\
& $\mathrm{K}_{2}(5,0)$ & $138,54 \mathrm{ab}$ \\
& $\mathrm{K}_{3}(7,5)$ & $167,16 \mathrm{a}$ \\
& $\mathrm{K}_{4}(10,0)$ & $171,34 \mathrm{a}$ \\
& $\mathrm{K}_{5}(12,5)$ & $194,46 \mathrm{a}$ \\
\hline 8 & $\mathrm{~K}_{0}($ Tanpa Perlakuan) & $54,06 \mathrm{~b}$ \\
& $\mathrm{~K}_{1}(2,5)$ & $123,21 \mathrm{ab}$ \\
& $\mathrm{K}_{2}(5,0)$ & $152,70 \mathrm{ab}$ \\
& $\mathrm{K}_{3}(7,5)$ & $184,74 \mathrm{a}$ \\
& $\mathrm{K}_{4}(10,0)$ & $190,84 \mathrm{a}$ \\
& $\mathrm{K}_{5}(12,5)$ & $218,51 \mathrm{a}$ \\
\hline
\end{tabular}

Keterangan : Angka-angka yang diikuti oleh huruf yang sama dan pada waktu pengamatan yang sama menunjukkan berbeda tidak nyata pada Uji Beda Nyata Jujur (BNJ) pada taraf $=5 \%$

Hasil penelitian menunjukkan bahwa perlakuan konsentrasi pupuk organik cair $12,50 \mathrm{ml} / \mathrm{L} \quad\left(\mathrm{K}_{5}\right)$ meningkatkan panjang tanaman binahong pada umur 5-8 MST hingga $218,51 \mathrm{~cm}$. Hal ini menunjukkan bahwa semakin tinggi konsentrasi pupuk organik cair yang diberikan dapat meningkatkan pertumbuhan vegetatif tanaman binahong. Hasil analisis tanah yang digunakan menunjukkan ketersediaan unsur hara $\mathrm{N}$ sebesar $0,17 \%$ dan hasil analisis pupuk organik cair (POC) menunjukkan ketersediaan unsur hara $\mathrm{N}$ sebesar $0,20 \%$. Nitrogen yang merupakan unsur hara utama bagi pertumbuhan tanaman umumnya sangat diperlukan untuk pembentukan atau pertumbuhan bagian-bagian vegetatif tanaman, seperti daun, batang dan akar (Yanti, 2014), pupuk organik cair juga berfungsi menggemburkan lapisan permukaan tanah, mempertinggi daya serap tanaman dan daya simpan air yang keseluruhannya meningkatkan kesuburan tanah guna meningkatkan pertumbuhan vegetatif tanaman. Hal tersebut dapat dibuktikan dari jumlah daun dan jumlah cabang tanaman binahong yang dihasilkan (Tabel 2 dan 3). Pada perlakuan konsentrasi pupuk organik cair $12,50 \mathrm{ml} / \mathrm{L} \quad\left(\mathrm{K}_{5}\right)$ menghasilkan jumlah daun dan jumlah cabang tanaman binahong tertinggi masing-masing sebesar 52,63 helai dan 1,73 buah. 
Tabel 2. Jumlah daun tanaman binahong umur 5-8 MST pada perlakuan konsentrasi pupuk organik cair

\begin{tabular}{|c|c|c|}
\hline $\begin{array}{l}\text { Pengamatan } \\
\text { (MST) }\end{array}$ & $\begin{array}{c}\text { Konsentrasi } \\
\text { Pupuk Organik Cair (ml/l) }\end{array}$ & $\begin{array}{l}\text { Rataan } \\
\text { (helai) }\end{array}$ \\
\hline \multirow{6}{*}{5} & $\mathrm{~K}_{0}($ Tanpa Perlakuan $)$ & $4,63 \mathrm{c}$ \\
\hline & $\mathrm{K}_{1}(2,5)$ & $13,50 \mathrm{bc}$ \\
\hline & $\mathrm{K}_{2}(5,0)$ & $16,63 b c$ \\
\hline & $\mathrm{K}_{3}(7,5)$ & $22,25 \mathrm{ab}$ \\
\hline & $\mathrm{K}_{4}(10,0)$ & $26,75 \mathrm{ab}$ \\
\hline & $\mathrm{K}_{5}(12,5)$ & $34,25 \mathrm{a}$ \\
\hline \multirow{6}{*}{6} & $\mathrm{~K}_{0}$ (Tanpa Perlakuan) & $6,00 \mathrm{c}$ \\
\hline & $\mathrm{K}_{1}(2,5)$ & $16,63 \mathrm{bc}$ \\
\hline & $\mathrm{K}_{2}(5,0)$ & $19,75 b c$ \\
\hline & $\mathrm{K}_{3}(7,5)$ & $26,88 \mathrm{ab}$ \\
\hline & $\mathrm{K}_{4}(10,0)$ & $32,50 \mathrm{ab}$ \\
\hline & $\mathrm{K}_{5}(12,5)$ & $40,63 \mathrm{a}$ \\
\hline \multirow[t]{6}{*}{7} & $\mathrm{~K}_{0}$ (Tanpa Perlakuan) & $7,50 \mathrm{c}$ \\
\hline & $\mathrm{K}_{1}(2,5)$ & $19,25 b c$ \\
\hline & $\mathrm{K}_{2}(5,0)$ & $23,13 b c$ \\
\hline & $\mathrm{K}_{3}(7,5)$ & $31,00 \mathrm{ab}$ \\
\hline & $\mathrm{K}_{4}(10,0)$ & $37,63 \mathrm{ab}$ \\
\hline & $\mathrm{K}_{5}(12,5)$ & $46,00 \mathrm{a}$ \\
\hline \multirow[t]{6}{*}{8} & $\mathrm{~K}_{0}$ (Tanpa Perlakuan) & $9,00 \mathrm{c}$ \\
\hline & $\mathrm{K}_{1}(2,5)$ & $22,75 b c$ \\
\hline & $\mathrm{K}_{2}(5,0)$ & $27,50 \mathrm{bc}$ \\
\hline & $\mathrm{K}_{3}(7,5)$ & $35,88 \mathrm{ab}$ \\
\hline & $\mathrm{K}_{4}(10,0)$ & $44,50 \mathrm{ab}$ \\
\hline & $\mathrm{K}_{5}(12,5)$ & $52,63 \mathrm{a}$ \\
\hline
\end{tabular}

Keterangan : Angka-angka yang diikuti oleh huruf yang sama dan pada waktu pengamatan yang sama menunjukkan berbeda tidak nyata pada Uji Beda Nyata Jujur (BNJ) pada taraf $=5 \%$

Semakin tinggi konsentrasi pupuk organik cair yang diberikan memberikan dampak positif terhadap pertumbuhan vegetatif tanaman binahong. Hal tersebut didukung oleh literatur Baskoro dan Purwoko (2010) yang menyatakan bahwa pemberian pupuk organik mampu memberikan pengaruh terbaik terhadap pertumbuhan tanaman. Atmojo (2003) menyatakan bahwa penambahan pupuk organik cair merupakan salah satu cara untuk meningkatkan pertumbuhan tanaman dan kandungan unsur hara dalam tanah.

\section{Jumlah Daun}

Tabel 2 menunjukkan bahwa perlakuan konsentrasi pupuk organik cair 12,50 ml/L $\left(\mathrm{K}_{5}\right)$ meningkatkan bobot segar tajuk tanaman binahong sebesar 30,41 g yang berbeda tidak nyata dengan $\mathrm{K}_{1}, \mathrm{~K}_{2}, \mathrm{~K}_{3}$ dan $\mathrm{K}_{4}$, namun berbeda nyata dengan $\mathrm{K}_{0}$. Pada penelitian ini menunjukkan bahwa semakin tinggi konsentrasi pupuk organik cair yang diberikan dapat meningkatkan pertumbuhan vegetatif tanaman binahong yang berbanding lurus dengan hasil akhir produktivitas tanaman yang dihasilkan. Dalam proses fisiologi tanaman peningkatan produktivitas suatu tanaman akan meningkat jika proses metabolisme didalam suatu tanaman berlangsung dengan baik. 
Tabel 3. Bobot segar dan bobot kering tajuk tanaman binahong pada perlakuan konsentrasi pupuk organik cair

\begin{tabular}{lcc}
\hline $\begin{array}{c}\text { Konsentrasi } \\
\text { Pupuk Organik Cair }(\mathrm{ml} / \mathrm{l})\end{array}$ & $\begin{array}{c}\text { Bobot Segar Tajuk } \\
(\mathrm{g})\end{array}$ & $\begin{array}{c}\text { Bobot Kering Tajuk } \\
(\mathrm{g})\end{array}$ \\
\hline $\mathrm{K}_{0}($ Tanpa Perlakuan) & $5,39 \mathrm{~b}$ & $1,89 \mathrm{c}$ \\
$\mathrm{K}_{1}(2,5)$ & $11,91 \mathrm{ab}$ & $3,31 \mathrm{bc}$ \\
$\mathrm{K}_{2}(5,0)$ & $17,05 \mathrm{ab}$ & $6,81 \mathrm{abc}$ \\
$\mathrm{K}_{3}(7,5)$ & $30,39 \mathrm{a}$ & $9,72 \mathrm{a}$ \\
$\mathrm{K}_{4}(10,0)$ & $18,21 \mathrm{ab}$ & $6,21 \mathrm{abc}$ \\
$\mathrm{K}_{5}(12,5)$ & $30,41 \mathrm{a}$ & $9,06 \mathrm{ab}$ \\
\hline
\end{tabular}

Keterangan : Angka-angka yang diikuti oleh huruf yang sama menunjukkan berbeda tidak nyata pada Uji Beda Nyata Jujur (BNJ) pada taraf $=5 \%$

Diduga pemberian pupuk organik cair hingga konsentrasi $12,50 \mathrm{ml} / \mathrm{L}$ mampu menjaga kestabilan proses metabolisme yang berlangsung dalam proses fotosintesis pada tanaman binahong sehingga menghasilkan fotosintat yang tinggi. Semakin tinggi hasil fotosintat yang dihasilkan dapat meningkatkan pertumbuhan vegetatif tanaman (daun, batang maupun akar). Hal tersebut dapat dilihat dari panjang tanaman, jumlah daun dan jumlah cabang tanaman binahong yang dihasilkan. Pemberian pupuk organik cair hingga konsentrasi 12,50 ml/L mampu meningkatkan panjang tanaman, jumlah daun dan jumlah cabang tanaman binahong masing-masing sebesar 218,51 cm, 52,63 helai dan 1,73 buah. Berhubungan dengan pernyataan Gardner et al. (1991) bahwa sepanjang pertumbuhan vegetatif, akar, daun, dan batang merupakan sink yang kompetitif dalam hal hasil asimilasi. Proporsi hasil asimilasi yang dibagikan ke ketiga organ tersebut dapat mempengaruhi pertumbuhan tanaman dan produktivitas.

\section{Bobot Segar Tajuk}

Data pengamatan bobot segar tajuk tanaman binahong dapat dilihat pada Tabel 4 . Berdasarkan table tersebut diketahui bahwa konsentrasi pupuk organik cair berbagai level perlakuan memberikan pengaruh nyata terhadap bobot segar tajuk tanaman binahong.
Tabel 3 menunjukkan bahwa pada bobot segar tajuk tanaman binahong tertinggi diperoleh pada perlakuan konsentrasi pupuk organik cair 12,50 $\mathrm{ml} / \mathrm{l}\left(\mathrm{K}_{5}\right)$ yang berbeda tidak nyata $\mathrm{K}_{1}, \mathrm{~K}_{2}, \mathrm{~K}_{3}$ dan $\mathrm{K}_{4}$, namun berbeda nyata dengan $\mathrm{K}_{0}$.

\section{Bobot Kering Tajuk}

Tabel 3 menunjukkan bahwa pada bobot kering tajuk tanaman binahong tertinggi diperoleh pada perlakuan konsentrasi pupuk organik cair 7,50 ml/l $\left(\mathrm{K}_{3}\right)$ yang berbeda tidak nyata $\mathrm{K}_{2}, \mathrm{~K}_{4}$ dan $\mathrm{K}_{5}$, namun berbeda nyata dengan $\mathrm{K}_{0}$ dan $\mathrm{K}_{1}$.

\section{Bobot Segar Akar}

Berdasarkan Tabel 4 dapat diketahui bahwa pada bobot segar akar tanaman binahong tertinggi diperoleh pada perlakuan konsentrasi pupuk organik cair 5,00 ml/l $\left(\mathrm{K}_{2}\right)$ yang berbeda tidak nyata dengan perlakuan lainnya. 
Tabel 4. Bobot segar dan bobot kering akar tanaman binahong pada perlakuan konsentrasi pupuk organik cair

\begin{tabular}{lcc}
\hline $\begin{array}{c}\text { Konsentrasi } \\
\text { Pupuk Organik Cair }(\mathrm{ml} / \mathrm{L})\end{array}$ & $\begin{array}{c}\text { Bobot Segar Akar } \\
(\mathrm{g})\end{array}$ & $\begin{array}{c}\text { Bobot Kering Akar } \\
(\mathrm{g})\end{array}$ \\
\hline $\mathrm{K}_{0}$ (Tanpa Perlakuan) & 0,34 & $0,09 \mathrm{~b}$ \\
$\mathrm{~K}_{1}(2,5)$ & 0,50 & $0,14 \mathrm{~b}$ \\
$\mathrm{~K}_{2}(5,0)$ & 6,07 & $0,34 \mathrm{ab}$ \\
$\mathrm{K}_{3}(7,5)$ & 2,16 & $0,83 \mathrm{a}$ \\
$\mathrm{K}_{4}(10,0)$ & 1,04 & $0,38 \mathrm{ab}$ \\
$\mathrm{K}_{5}(12,5)$ & 1,70 & $0,68 \mathrm{ab}$ \\
\hline
\end{tabular}

Keterangan : Angka-angka yang diikuti oleh huruf yang sama menunjukkan berbeda tidak nyata pada Uji Beda Nyata Jujur (BNJ) pada taraf $=5 \%$

\section{Bobot Kering Akar}

Tabel 4 menunjukkan bahwa pada bobot kering akar tanaman binahong tertinggi diperoleh pada perlakuan konsentrasi pupuk organik cair 7,50 ml/ $\left(\mathrm{K}_{3}\right)$ yang berbeda tidak nyata $\mathrm{K}_{2}, \mathrm{~K}_{4}$ dan $\mathrm{K}_{5}$, namun berbeda nyata dengan $\mathrm{K}_{0}$ dan $\mathrm{K}_{1}$. Hasil penelitian menunjukkan bahwa perlakuan konsentrasi pupuk organik cair 7,50 $\mathrm{ml} / \mathrm{L} \quad\left(\mathrm{K}_{3}\right)$ meningkatkan bobot segar akar, bobot kering akar dan bobot segar rimpang tanaman binahong masing-masing sebesar 2,16 g, 0,83 $\mathrm{g}$ dan 32,56 g dibandingkan dengan perlakuan konsentrasi pupuk organik cair 12,50 ml/1 ( $\left.\mathrm{K}_{5}\right)$. Pada kondisi penelitian ini pemberian pupuk organik cair dengan konsentrasi 7,50 ml/l meningkatkan pertumbuhan vegetatif tanaman pada bagian akar. Menurut hasil penelitian Baskoro dan Purwoko (2010) menunjukkan bahwa perlakuan pupuk organik memberikan pengaruh nyata terhadap tinggi tanaman, jumlah dan lebar daun, bobot basah dan bobot kering akar, bobot basah dan bobot kering batang, bobot basah dan bobot kering total tanaman, dan bobot basah daun pada tanaman binahong. Hal tersebut juga sejalan dengan Penelitian Yanti (2014) yang menyebutkan bahwa pemberian pupuk sangat erat kaitannya dengan fase pertumbuhan vegetatif dan generatif. Nitrogen merupakan unsur hara utama tanaman bagi pertumbuhan tanaman, pada umumnya sangat diperlukan untuk pembentukan atau pertumbuhan bagian-bagian vegetatif tanaman, seperti daun, batang dan akar. Berdasarkan hasil analisis statistik dapat diketahui bahwa perlakuan konsentrasi pupuk organik cair berpengaruh nyata terhadap panjang tanaman umur $2-8 \mathrm{MST}$, jumlah daun umur 2-8 MST, jumlah cabang umur 4 8 MST, bobot segar tajuk, bobot kering tajuk, bobot kering akar dan bobot segar rimpang tanaman binahong.

\section{SIMPULAN}

Pemberian pupuk organik cair dengan konsentrasi 12,50 $\mathrm{ml} / \mathrm{l} \quad$ (K5) memberikan pengaruh nyata meningkatkan pertumbuhan panjang tanaman, jumlah daun, dan jumlah cabang tanaman binahong. Pemberian pupuk organik cair dengan konsentrasi 12, $50 \mathrm{ml} / \mathrm{l}$ (K5) memberikan pengaruh tidak nyata terhadap konsentrasi 2,50 ml/l (K1), 5,00 ml/1 (K2), 7,50 ml/l (K3), dan $10 \mathrm{ml} / \mathrm{l}$ (K4) pada bobot segar tajuk tanaman binahong. Pemberian pupuk organik cair dengan konsentrasi 7,50 $\mathrm{ml} / \mathrm{l} \quad$ (K3) memberikan pengaruh nyata meningkatkan pertumbuhan bobot segar akar, bobot kering akar, dan bobot segar rimpang tanaman binahong. Aplikasi pupuk organik cair (POC) Jika melakukan penelitian yang sama, sebaiknya konsentrasi pupuk organik cair (POC) dioptimalkan pada konsentrasi 7,5 ml/L. 


\section{DAFTAR PUSTAKA}

Atmojo, S.W. 2003. Peranan Bahan Organik Terhadap Kesuburan Tanah dan Upaya Pengelolaannya. Sebelas Maret University Press. Surakarta.

Astuti, S.M., Sakinah M.A.M., Andayani, R.B.M., Risch, A., 2011. Determination Of Saponin Compound From Anredera Cordifolia (Ten) Steenis Plant (Binahong) to Potential Treatment For Several Diseases. Journal of Agicultural Science. Vol 3, No 4; Desember 2011.

Baskoro, D dan Purwoko, B.S., 2010. Pengaruh Bahan Perbanyakan Tanaman dan Jenis Pupuk Organik Terhadap Pertumbuhan Tanaman Binahong (Anredera cordifolia (Ten.) Steenis). Jurnal Hortikultura Indonesia 2(1):6-13. Agustus 2010.

Gardner, W. J., R. B. Pearce dan R. L. Mitchell. 1991. Fisiologi Tanaman. Terjemahan Herawati, S. UI Press, Jakarta. Hal: 8, 205, 216.

Mus. 2008. Informasi Spesies Binahong Anredera cordifolia (Ten.) Steenis. www. plantamor.com. [16 Januari 2016].

Tatik., T. Rahayu., M. Ihsan. 2014. Kajian Perbanyakan Vegetatif Tanaman Binahong (Anredera cordifolia (Ten.) Steenis) Pada Beberapa Media Tanam. Jurnal Agonomika, Vol 09, No 02. Februari - Juli 2014.

Yanti, N. 2014. Pengaruh Konsentrasi Dan Interval Pemberian Pupuk Organik Cair Asal Sabut Kelapa Dan Chromolaena odorata Pada Padi gogo (Orsyza sativaL.). Jurnal Progam Studi Agoekoteknologi Fakultas Pertanian. Universitas Taman Siswa Padang. Padang. 